\title{
IGOR BORKOWSKI
}

\section{Kronika szkolna - specyficzne narzędzie kształtowania obrazu wojny i żołnierza}

\section{Abstrakt}

Status kroniki szkolnej jako zespołu gatunkowego odnoszącego się do dokumentów życia społecznego $\mathrm{z}$ dzisiejszej perspektywy wydaje się dysfunkcyjny. Inne są już bowiem kanały komunikacji, przekazu wartości, kształtowania postaw i budowania wzorców. Kronika szkolna wciąż może jednak stanowić interesujący zasób materiału obrazującego żywe i aktualizowane w przekazie perswazyjnym lub propagandowym środki i narzędzia, które pozwalają skutecznie wpływać na postawy, idee, poglądy i decyzje odbiorców, kształtować ich postawy światopoglądowe czy konstruować wzorce osobowe o charakterze parenetycznym.

Tekst koncentruje się na analizach materiałów z kronik szkolnych, które dotyczą obrazu wojny i wizerunku żołnierza.

Słowa kluczowe: propaganda, wojna, żołnierz, kronika szkolna.

Status kroniki szkolnej jako zespołu gatunkowego odnoszącego się do dokumentów życia społecznego z dzisiejszej perspektywy wydaje się dysfunkcyjny. Inne są już bowiem kanały komunikacji, przekazu wartości, kształtowania postaw i budowania wzorców. Wydaje się jednak, że kronika szkolna wciąż może być interesującym zasobem materiału obrazującego żywe i aktualizowane w przekazie perswazyjnym lub propagandowym środki i narzędzia, które pozwalają skutecznie wpływać na postawy, idee, poglądy i decyzje odbiorców, kształtować ich postawy światopoglądowe czy konstruować wzorce osobowe o charakterze parenetycznym.

Spojrzenie na zasób kronikarski z perspektywy badań nad propagandą i jej wysłowieniem otwiera bardzo ciekawe pola obserwacji. Kroniki pośrednio bywają także zasobem kolejnych materiałów, gromadząc je i archiwizując w swoich ramach. Tak dzieje się choćby z dokumentami życia społecznego, które - również w kontekście powojennej historii Dolnego Śląska - jako istotny materiał badawczy traktuje Marta Śleziak w książce Ziemie Odzyskane w drukach ulotnych $z$ lat 1945-1948, przywołując też stanowiska innych badaczy, którzy druki i zapisy o charakterze kronikarskim czy pamiętnikarskim uznają za realizujące nie tylko funkcje 
informacyjne i dokumentacyjne, lecz także pedagogiczne (zapewne perswazyjne) i propagandowe ${ }^{1}$.

W niniejszym tekście zgromadzone zostały przykłady wykorzystania kroniki szkolnej jako narzędzia propagandowego do budowania obrazu wojny i wizerunku żołnierza. Materiałem przykładowym i ilustracyjnym są kroniki szkolne z lat 1965-1989 Szkoły Podstawowej nr 3 im. Generała Karola Świerczewskiego-Waltera $^{2}$ w Strzelinie. Wszystkie dane, cytaty i przykłady pochodzą z kroniki głównej szkoły (nie z kronik klasowych, które także były redagowane, przynosząc, co może być zaczynem innego wątku badań, reminiscencje i stałe nawiązania do kierunku propagandowego wytyczanego przez kronikę nadrzędną).

Kronika ze swej natury jest strukturą hipertekstualną odnoszącą się do „aktualnej przeszłości” - notyfikuje przebieg zdarzeń, by je upamiętnić, zatrzymać w kadrze wspomnień, a dla potomnych stać się dowodem archiwizującej pracy „ku pamięci” zdarzeń, w których społeczność tworząca tekst kronikarski (zwykle poprzez upoważnionego do tego reprezentanta - kronikarza) w kontekście bieżących zdarzeń snuje opowieść pozytywną wizerunkowo, perswazyjnie ukształtowaną, przemyślaną i co najmniej autocenzorsko korygowaną.

Szkolne kroniki z czasów PRL odbiegają od tej charakterystyki, stając się w pierwszej kolejności narzędziem komunikacji propagandowej, zapośredniczającej w sposób bardzo czytelny konstrukty językowe, utarte zwroty, szablony i klisze z przestrzeni wysłowienia propagandowego. Są konsekwentnie i starannie realizowanym wykładem dotyczącym tych wartości, które dla nadawcy - dysponenta treści propagandowej - nie tylko archiwizują rzeczywistość, oddając realne zdarzenia w porządkującym i syntetyzującym oświetleniu i skrócie, lecz przede wszystkim budują narrację założoną i naddaną niejako spoza tej rzeczywistości, którą miałyby funkcjonalnie archiwizować.

Michał Głowiński, rozważając wartości sztuki socrealistycznej, zwrócił — w moim mniemaniu trafnie także w odniesieniu do omawianego tutaj zbioru tekstów - uwagę na komunikacyjne blokady wysłowienia propagandowego. Językiem tym - ze specyficznie usytuowanymi relacjami nadawczo-odbiorczymi, stylem, podstawową hierarchią funkcji - nie można niewinnie, faktograficznie „opowiadać”:

na podstawie tego, co o niej [nowomowie - I.B.] wiemy, z góry możemy wykluczyć ze sfery jej działania relacje typu veni, vidi, vici. Jednakże narracja może przecież ustalać (i wielekroć to robi), co jest słuszne, a co nie jest, może relacjonować fakty nie w tym celu, by zdać z nich sprawę, ale by projektować zachowania tych, którzy zechcą się z nią zapoznać, albo wręcz je narzucać [...]. W istocie zagadnienie to obejmuje nie tylko literaturę: ma zasięg szerszy, łączy się z problemami, które w ogólności przynosi totalitarna forma. (Głowiński 1992: 19)

${ }^{1}$ Por. Śleziak 2016: 18-19; Słomianowska-Kamińska 2006: 128-141.

${ }^{2}$ Szczegółowo o kształtowaniu i funkcjonalizacji parenetycznego mitu postaci Karola Świerczewskiego pisze Piotr Osęka w rozdziale Szczerbców i krakusów mit w Osęka 2010: 79-89. 
Ciekawe wydaje się, po pierwsze, nakreślenie schematu komunikacyjnego, w którym lokuje się kronika szkolna jako tekst, a po drugie, zlokalizowanie miejsca, w którym się ona znajduje. Kronika szkolna nie jest bowiem tekstem kreowanym spontanicznie. Jako że jej status jest kancelaryjno-archiwizacyjny, a sposób wykorzystania i użyteczność - oficjalna, staje się ona przestrzenią, w której realizuje się zaprojektowana i kontrolowana akumulacja zdarzeń. Tekst tego typu pełni funkcje reprezentacyjne, ma charakter promocyjny czy autopromocyjny, odnośnie do społeczności lub instytucji. To właśnie zinstytucjonalizowanie kroniki jako projektowanej struktury, a także procedura kwalifikowania jej autora pozwalają sądzić, że jest to materiał o statusie specyficznym, filtrowanym, zarówno pod względem autocenzury, jak i ewentualnej cenzury prewencyjnej. Ma ona miejsce najpierw przy wskazaniu osoby, która ma się zająć redagowaniem wpisów w kronice. Zwykle czasowo jest to jedna osoba, często wskazana $\mathrm{z}$ imienia i nazwiska, a sama funkcja kronikarza również w kontekście obyczajowości szkolnej — postrzegana jest jako nobilitująca i wyróżniająca. Wiąże się z nią w wypadku kroniki szkolnej, a więc reprezentatywnej nie tylko dla zmiennej co do składu osobowego społeczności, lecz także trwającej na przestrzeni lat instytucji oświatowej, element kreowania komunikacji wizerunkowej, wskazującej na znajomość, akceptację i realizację porządku ideologicznego. Kronika staje się zatem wzorcowym wręcz przykładem ilustrującym model komunikacji oficjalnej PRL, który zrekonstruowała Irena Kamińska-Szmaj, wskazując na daleko idącą instrumentalizację mediów, centralne sterowanie, jednokierunkowość, sprowadzenie mediów pod kontrolą rządzących do roli jedynie "przekazujących i wytwarzających teksty kontrolowane przez rządzących" (2007: 14-16). Taki status kroniki sugeruje, że nie jest ona redagowana z myślą o aktualnej lekturze, zapisy w niej nie są na bieżąco udostępniane, nie czyta się ich, nie komentuje, nie dialoguje z nimi w żaden sposób. Raczej stają się one elementem petryfikowanej i ustalanej deklaratywnie wizji zdarzeń przeszłych, notowanych z myślą o dowodowym ich utrwaleniu, ewentualnie funkcjonalizowaniu jako narzędzi komunikacji wizerunkowej, promocyjnej, udowadniającej pozycję szkoły w środowisku, skuteczną pracę dyrekcji i zespołu wychowawczego, postawę ideologiczną społeczności szkolnej: dyrekcji, nauczycieli, pracowników administracji i obsługi, uczniów i ich rodziców. Kronika tego typu miała raczej status dowodowy w sytuacji, gdy należy tę postawę udowodnić, uruchamiana była najczęściej nie tyle do ewentualnej indywidualnej lektury, ile do działań o charakterze rytualnym, jako pewnego typu cenna relikwia pamięci przeznaczona do oglądania i podziwiania. Jej ważną cechą jest językowy i estetyczny konserwatyzm. Nie ma tu w zasadzie przez cały omawiany okres żadnych dowodów na to, by nadawca uznał, że został „skazany na proste słowa”3.

Istotnym elementem w opisywanej tu sytuacji komunikacyjnej jest więc zarówno wąski krąg nadawczy, jak i zapewne niezbyt liczny i okazjonalny krąg odbiorczy.

${ }^{3}$ Irena Kamińska-Szmaj w książce Słowa na wolności bardzo ciekawie pokazuje, jak owo „skazanie" zmusiło dysponenta propagandy do korekty wysłowienia totalitarnego około roku $1980 \mathrm{i}$ jak nieskuteczna była późniejsza recydywa stylistyki nowomowy; por. Kamińska-Szmaj 2001: 13-37. 
Można wnioskować, że kronika miała raczej charakter pewnego deklaratywu ${ }^{4}$, a nie żywego i aktywnego elementu komunikacji o szkole, wydarzeniach z nią związanych czy pouczającej historii. Pozwala to na wskazanie daleko idących zbieżności ze zrekonstruowanym modelem komunikacji w odniesieniu do pragmatyki komunikacyjnej haseł pierwszomajowych, w których zamiast oczekiwanej korespondencji między nadawcą i odbiorcą pojawia się mechanizm, który zamienia miejscami pierwotnych nadawców i odbiorców, podstawia ich lub przywołuje powtórnie. Ostatecznie ciąg tych roszad prowadzi wyłącznie do wzmagania kontroli nad przekazem:

W wypadku pierwszomajowych haseł pierwotny nadawca to jeden $\mathrm{z}$ ostatnich odbiorców, nie był on jednak neutralny w tym bezgłośnym często akcie komunikacji — odbiorca ostateczny pełnił funkcję kontrolującą, miał okazję sprawdzić, na ile podporządkowano się jego zaleceniom. Funkcja kontrolująca staje się funkcją najważniejszą, organizującą „życie”. (Dytman-Stasieńko 2006: 127)

Brakuje równocześnie dowodów na to, by kroniki szkolne były jakkolwiek aktualizowane i używane na przykład do prowadzenia lekcji historii, jako pomoce dydaktyczne do lekcji wychowawczych czy wiedzy o społeczeństwie.

Wojna i żołnierz w perspektywie kroniki szkoły, której patronem był reprezentant armii, uczestnik walk rewolucyjnych w Hiszpanii, następnie uczestnik i dowódca na szlaku bojowym Armii Czerwonej i II Armii Wojska Polskiego, budowniczy powojennego kształtu Polski jawią się tak, jak te kategorie widziała i postrzegała, a także jak je funkcjonalizowała, ogólnokrajowa machina propagandowa. Sztampowość formy i treści oraz środków wyrazu wskazuje na wysoki stopień zapośredniczenia w oficjalnych wzorcach propagandowych, wzorcach osobowych, interpretacyjnych, wykładnikach językowych i w symbolicznej oraz plastycznej wizualizacji. Zespół tekstów i towarzyszących im materiałów dokumentalnych (odręcznych ilustracji, wyklejanek i wydzieranek, rysunków oraz fotografii) bardzo często wzbogacany jest wycinkami z pracy ogólnokrajowej, dobieranymi w taki sposób, by stanowiły potwierdzenie w kontekście ogólnopolskim tych działań i tej interpretacji zdarzeń, które ujawniają się w kontekście podejmowanych lokalnie, w odniesieniu do konkretnej szkolnej społeczności zdarzeń. Układa się ona w jednolity front ideologicznego oddziaływania na najmłodszych.

O strategicznym kształtowaniu narracji biograficznej dotyczącej Karola Świerczewskiego pisze Paweł Smoleński:

Jego [Świerczewskiego - I.B.] losy to dowód, jak można z niczego, lekceważąc prawdę, napisać historię. Co tam historię! Można napisać teraźniejszość, która - choć działa się nieledwie wczoraj — zamienia się w legendę. (Smoleński 2017: 73)

4 „Deklaratyw” rozumiem tu jako pewną kolekcję zapisanych dowodnie deklaracji prawowierności systemowi, jego linii ideologicznej oraz narzędziom i stylistyce wysłowienia propagandowego na poziomie doboru środków językowych, argumentacji, mechanizmów manipulacyjnych zarówno na poziomie języka, jak i estetyki. Manifestowanie wierności wysłowieniu nowomowy jest tu realizowane konsekwentnie i w zasadzie niezmienne, stoi niejako poza nurtem zmian, które od roku 1980 (lub nieco wcześniej) obserwują i opisują dowodnie badacze propagandy politycznej i jej języka; Kamińska-Szmaj 2001, 2007; Borkowski 2003; Ożóg 2004; Głowiński 1996, 1999. 
Zdarzenia, rocznice, uroczystości - te dalekie i te najbliższe szkolnej społeczności - są traktowane w jednakowy sposób, przede wszystkim jako okazja do wzmożenia oddziaływań propagandowych. W omawianym tu wypadku: zwłaszcza w aktualizowaniu sceny wojny, wysiłku zbrojnego i losu żołnierza. Tak dzieje się w ciekawym zapisie dotyczącym uroczystości „XX rocznicy Ziemi Strzelińskiej z okazji powrotu do Macierzy po siedmiowiecznej niewoli”. W szkolnej kronice notuje się i wylicza sukcesy budownictwa socjalistycznego, odbudowę ze zniszczeń wojennych, ale też dokumentuje, że głównym nurtem pracy szkolnej dla uczczenia wydarzeń jubileuszowych był „konkurs recytatorski poezji o tematyce wojennej” (21.01.1965). Szkolne apele, uroczystości wspomnieniowe, spotkania z zaproszonymi gośćmi, wieczornice poetyckie i alerty harcerskie wpisują się każdorazowo w kontrolowany dukt ideologiczny kształtowany przez dysponenta przekazu propagandowego na szczeblu centralnym. Dzień Zwycięstwa trafia na przykład na karty kroniki jako emocjonalnie aktywna kolekcja ilustracji: opatrzona wycinkiem tytułu $\mathrm{z}$,Trybuny Ludu” - „Wobec idei pokoju”, plakatem propagandowym z tekstem zapisanym cyrylicą: „9 maja 1945” oraz wycinkami prasowymi: „Wychowanie dla pokoju” oraz „Protesty przeciwko zbrojeniom w Stanach Zjednoczonych” (9.05.1974).

$\mathrm{W}$ badanym materiale potwierdza się to, co wiemy doskonale na temat komunikacji o charakterze propagandowym w systemie totalitarnym. Jest ona poddana daleko idącej standaryzacji, odwołuje się do szybko petryfikujących się wzorców, których ewentualne korekty czy przekształcenia następują w zasadzie tylko na wyraźną dyspozycję ze strony tego, kto o kształcie tej komunikacji decyduje. Nierzadko zapewne, czego obserwacja kostnienia sposobów wysławiania się propagandy w czasach PRL wyraźnie dowiodła, staje się przyczynkiem do jej ostatecznej dysfukcjonalizacji. Standaryzacja staje się nieznośną manierą, ostatecznie zniewala i prowadzi do antykomunikacyjnej sztampy. Tak też dzieje się w wypadku szkolnych kronik. Przepełnione są one swoistymi dowodami na ćwiczenia poprawnego wysławiania propagandowego: wizualne, kompozycyjne, stylistyczne i semantyczne. Trafność i udatność we wcielaniu się w odpowiednie role, przyjmowanie trafnych strategii odwzorowywania wysłowienia propagandowego w jego oficjalnej wersji staje się tu przesłanką dowodzącą opanowania w wysokim stopniu zadanego przez dysponenta treści i formy propagandowej materiału treningowego.

Umieszczanie lokalnych zdarzeń, także tych wewnątrzszkolnych, w szerokim nurcie wydarzeń o wymiarze krajowym, aktualnym czy wręcz historycznym, jest tu w oczywisty sposób narzędziem indoktrynacyjnym. Wpisuje się w podejmowane przez propagandę wysiłki legitymizacji władzy w kontekście historiozoficznym. Dlatego też szlak bojowy żołnierza nie zaczyna się w jakimś realnym historycznie kontekście, ale wyznaczany jest powracającymi regularnie w perspektywie dziejów zmaganiami z niemieckim agresorem, w budowanej niezmiennie przyjaźni z Armią Czerwoną i jej reprezentantami - znanymi i wskazywanymi z imienia i nazwiska wyzwolicielami miast i wsi na Dolnym Śląsku. Ten personalizacyjny zabieg wydaje się nie tylko ciekawy, lecz także pomysłowy. Kroniki dokumentują zawiązywanie 
i kultywowanie relacji z poszczególnymi kombatantami - ówcześnie obywatelami Związku Radzieckiego. Pamięta się o nich, opisuje ich historię bojową, również powojenne losy, regularnie ponawia kontakt korespondencyjny, a jednymi z najważniejszych wydarzeń są wizyty radzieckich kombatantów podczas wydarzeń szkolnych: jubileuszy, rocznicy rewolucji październikowej czy najbardziej adekwatnego tematycznie - Dnia Zwycięstwa. Każdorazowo otrzymujemy dokumentację fotograficzną, także artefakty dokumentalne: wpis odręczny do kroniki czy też jakieś odręczne poświadczenie pobytu lub reakcji na zainicjowany przez szkolną społeczność kontakt (list, koperta, karta pocztowa). Materialny wymiar działań propagandowych wydaje się elementem stale towarzyszącym działaniom werbalnym: „VI Kongres ZBoWiD - 7 V 79 odbił się żywym echem w pracy szkoły. Prezes M-G Zarządu - kombatant Jerzy Nowakowski uczestniczył w Kongresie. Zawiózł do Warszawy wykonane przez nas upominki: dwa proporczyki okolicznościowe i gobelin z Rotundą Gotarda” (7.05.1979) - tekst jest opatrzony zjadliwym emocjonalnie wycinkiem z prasy „Żadna Polka o tym nie zapomni. Modlitwa do niemieckiego Boga [pierwszy wers - I.B.]: Powal, o panie, bezwładem ręce i nogi Polaków...”.

Budowanie poczucia dumy, swoistego granfalonu, jest w kronice jednym $z$ istotnych, ale nie jedynym czy wyizolowanym, narzędzi perswazyjnych. Za każdym razem komunikacji podbudowanej pozytywnymi emocjami towarzyszą sygnały przypominające o zagrożeniu wojennym czy konieczności stałej walki o zachowanie równowagi militarnej między blokiem wschodnim i zachodnim, która miałaby być gwarantem światowego pokoju. Jest to dość oczywista konstatacja, ale warto ją uzupełnić spostrzeżeniami dotyczącymi wielonurtowości tej komunikacji: wątek dotyczący zagrożeń światowego pokoju ma praktycznie bezwyjątkowo potwierdzenia w materiałach zapośredniczonych z mediów - wycinków z prasy ogólnokrajowej lub regionalnej („Trybuna Ludu”, „Gazeta Robotnicza”), materiałów propagandowych emitowanych przez system partyjny lub przez urzędników nadzoru oświatowego. Treścią komunikacji kreowanej na spontaniczną, oddolną, wywodzącą się ze środowiska społeczności szkolnej, jest raczej akcentująca optymizm troska o pokój i duma $z$ kultywowania tradycji patriotycznych, budowania i podtrzymywania szacunku dla wysiłku militarnego, tradycji żołnierskich i munduru wojskowego. Co ważne, wysiłek ten jest starannie odnoszony do postaci żołnierza, nie przenosi się go na abstrakcyjny poziom wysiłku militarnego „państwa” czy „armii”. Są to pojęcia pomijane, identyfikuje się ofiarność, wysiłek, trud, także same dokonania frontowe jednostki, nawet jeśli prefigurowanej jako „żołnierz”, a nie personifikowanej. Gdy taka personifikacja się pojawia, dotyczy przede wszystkim żołnierzy - kombatantów Armii Czerwonej. Zinstytucjonalizowana Armia Radziecka stawiana jest bowiem jako wzór i armia-matka II Armii Ludowego Wojska Polskiego. Pamięta się o rocznicach związanych z jej historią, kultywuje pamięć o jej powstaniu oraz nawiązuje relacje $\mathrm{z}$ kombatantami:

60 rocznicę powstania Armii Czerwonej uczciliśmy: zaciągnięciem warty honorowej przy pomniku gen. Świerczewskiego i w szkolnej Izbie Pamięci Narodowej; porankiem szkolnym; spotka- 
niem kombatantów Armii Czerwonej z uczniami naszej szkoły; złożeniem kwiatów i zapaleniem zniczy na cmentarzu żołnierzy radzieckich w Wiązowie; napisaniem listu i wysłaniem upominku dla obywatela ZSRR Iwana Polikarpowicza — żołnierza, który wyzwalał Strzelin. (23.02.1978)

Warto zauważyć, że tego typu korespondencja nie jest jednostronna, nie pozostaje bez odzewu. Adresat odpowiada serdecznym listem i pozdrowieniami, które również trafiają do szkolnej kroniki.

Reprezentantami kategorii semantycznej „żołnierz polski” w badanym materiale są - indywidualnie - kreowany na ikonę i wzorzec generał Karol Świerczewski „Walter” lub uogólniony do kategorii grupowej „Dąbrowszczak”:

Konferencja poświęcona wychowaniu młodzieży na tradycjach II Armii LWP. W Konferencji uczestniczyli przedstawiciele wszystkich szkól w Polsce, których imię związane jest $\mathrm{z}$ bohaterami II Armii LWP [...]. Na tej konferencji nasza szkoła została odznaczona Medalem pamiątkowym Dąbrowszczaków. (24.04.1977)

System propagandowy pozwala nie tylko komunikować poprzez tego typu znaki, lecz także konstruuje z nich podręczny zbiór faktów, które stają się pretekstem do budowania dumy grupowej, podnoszenia morale i dowartościowywania odbiorców. Tak dzieje się, gdy przy wpisie z roku 1977 ilustrowanym zdjęciem z pochodu pierwszomajowego i hasłem „Wspólną pracą trudem wszystkich budujemy dom ojczysty" poza wyliczeniem osiągnięć, takich jak wyniki w konkursach przedmiotowych czy budowa boiska sportowego w czynie społecznym i we współpracy z zakładem patronackim - Strzelińską Fabryką Mebli, pojawia się adnotacja o: „przyznaniu nam medalu 100. rocznicy urodzin F. Dzierżyńskiego za Szkolną Izbę Pamięci Narodowej" (1.05.1977).

Sama przestrzeń Izby Pamięci Narodowej, jak określa się ją w kronice, ,jest naszą dumą" (9.05.1978). Staje się ona nie tylko narzędziem oddziaływań propagandowych, lecz także swoistą przestrzenią sakralną; znajdują się w niej odpowiednie eksponaty ilustrujące dzieje oręża polskiego, popiersie patrona szkoły, dokumentowany jest również wysiłek w rywalizacji uczniów - dwa dyplomy, puchary, medale i inne nagrody. Miejsce to jest też przestrzenią swoistych liturgii świeckich, takich jak zaciąganie warty honorowej czy składanie w pisemnej formie u stóp popiersia patrona uczniowskich ślubowań wychowawczych. Takie gesty znajdują swoje miejsce w kronice, jednocześnie przypominając o rytualizacji działań propagandowych i ich sakralizacji. W Izbie Pamięci, co dokumentuje się skrupulatnie w kronice, odbywają się lekcje, w tym lekcje uroczyste związane z ważnymi wydarzeniami: świętem żołnierskim lub uroczystościami ku czci patrona szkoły. Jest to element trwały, wraca stale, także pod koniec epoki, w zapisie z 1987 roku: „Lekcja w Izbie Pamięci Narodowej. Po raz drugi odwiedziliśmy Izbę Pamięci Narodowej, dowiedzieliśmy się o życiorysie gen. Karola Świerczewskiego" (29.03.1987). Sakralna przestrzeń Izby Pamięci Narodowej jest ustanawiana w sferze słów kroniki w taki sposób, że pokazuje przejrzyście, jak działają najistotniejsze mechanizmy nowomowy: narzucanie wyrazistych znaków wartości, rytualizacja i magiczność, o których Michał 
Głowiński pisze, że „słowa nie tyle odnoszą się do rzeczywistości, nie tyle ją opisują, co ją tworzą. To, co zostało autorytatywnie wypowiedziane, staje się rzeczywistością" (Głowiński 1991: 8).

Pojęcia nakładają się na siebie i przekształcają się nawzajem, budując swoisty amalgamat treści propagandowych, które ujawniają się w miejscach nieoczekiwanych. Gdy pojawia się wpis dotyczący Międzynarodowego Dnia Dziecka, ilustrowany jest następującym czterowierszem:

\author{
Niechaj pokój trwały \\ Świat obejmie cały \\ My nie chcemy wojny \\ Gołąbeczku biały! (1.06.1978)
}

$\mathrm{W}$ podobny sposób prezentuje się szkolne wydarzenia ważne z perspektywy rozpoczynających naukę w szkole najmłodszych, a także ich rodziców i starszych uczniów. Z tego względu uroczystość złożenia ślubowania na sztandar szkoły przez pierwszoklasistów, która odbywa się jeszcze we wrześniu, w szkolnej kronice jest dokumentowana jako wydarzenie, w czasie którego „dyrektor szkoły w powitalnym przemówieniu do nauczycieli, uczniów i rodziców przypomniała tragedię dni wrześniowych, przedstawiła zagadnienia programowe szkoły oraz w bardzo serdecznych słowach życzyła nam w nowym roku szkolnym samych sukcesów" (28.09.1977). Bardzo podobnie łączy się początek roku szkolnego z rocznicą wybuchu II wojny światowej. Kronikarski zapis oderwany od realnego kontekstu pozostawia wątpliwość dotyczącą relacji przyczynowo-skutkowej inaugurowania roku szkolnego właśnie 1 września: „1 września w rocznicę tragicznych wydarzeń września 1939 roku odbyło się w naszej szkole uroczyste rozpoczęcie nowego roku szkolnego" (1.09.1976).

Militaryzacja komunikacji na poziomie leksyki, metaforyki, semantyki tekstu i kontekstu obrazowego oraz ilustracyjnego wskazuje, że był to najchętniej i najczęściej wykorzystywany motyw treściowy analizowanego materiału. Otrzymujemy $\mathrm{w}$ nim $\mathrm{z}$ jednej strony dowody na realne zdarzenia, ich intencje, przebieg oraz założone i zrealizowane treści wychowania patriotycznego: kultu żołnierza, bohaterstwa frontowego, poświęcenia i siły (męstwa).

Wyrazistość tego obrazowania zapewne jest skuteczna, tak jak skuteczne jest odwoływanie się w języku i wyobrażeniu propagandowym do kontekstu wojny jako sceny metaforycznego obrazowania i wartościowania. Tu sprawa jest szczególnej wagi, ów kult propagandowy jest bowiem kształtowany u dzieci i młodzieży, dla których wojna i wysiłek zbrojny są historią, nie współczesnością. Jego aktualizacja, jak w całej ówczesnej propagandzie, budowała z jednej strony pozorny granfalon, z drugiej - realnie była narzędziem zastraszania i konsolidacji umotywowanej zewnętrznym zagrożeniem. Znajdujemy na to liczne potwierdzenia. W kronikach pojawiają się bowiem nie tylko liczne i powracające zapisy dotyczące zdarzeń o charakterze wspomnieniowym (apeli, wieczornic, inscenizacji, konkursów poetyckich 
czy plastycznych poświęconych tematyce militarnej), lecz także akceptującej korespondencji $\mathrm{z}$ oficjalnym kursem propagandowym, eksponującym militarystyczne zapędy krajów kapitalistycznych, niemieckie resentymenty rewizjonistyczne czy zagrożenie wybuchem konfliktu nuklearnego. To postawa dzieci i młodzieży ma się stać argumentem czy wprost kluczowym środkiem do zażegnania konfliktu. W rzeczywistości jest więc też narzędziem etycznego szantażu wobec poddawanych ideologicznym naciskom młodych ludzi, którzy stają się zakładnikami w propagandowej wojnie o pokój: „»Niech nam pokój szczęście da«. Pod takim hasłem opracowaliśmy występ na uroczyste plenum Komitetu Frontu Jedności Narodu” (12.04.1974).

Piotr Osęka zauważa w analizie kampanii propagandowych odnoszących się do kształtowania wizerunku wysiłku żołnierskiego z jednej, a zagrożenia militaryzmem zachodnim w propagandzie PRL z drugiej strony, również funkcje oskrzydlające: „pacyfistyczne slogany stanowiły też uzasadnienie terroru”, a także to, że „organizowanym $\mathrm{z}$ hukiem wielkim akcjom propagandowym towarzyszyła skryta, ale nie mniej intensywna rozbudowa armii i przemysłu zbrojeniowego" (Osęka 2010: 38, 41).

Badany materiał dostarcza zapisów ilustrujących intensyfikację, kampanijność, ale i jednowymiarowość oddziaływania propagandowego, na przykład w Dniu Patrona szkoły -26 marca:

Uroczyste lekcje w klasach. Projekcja filmu „Generał Walter”. Finał konkursu „Wiem wszystko o gen. K. Świerczewskim”. Przygotowanie akademii. 27 marca: Bieg patrolowy ZHP. 28 marca: Apel grupy wiekowej „Pacholąt”. Apel grupy wiekowej „Sztubaków”. Apel grupy wiekowej „Żaków". Capstrzyk pod pomnikiem gen. Karola Świerczewskiego. Obietnica zuchowa. Przyrzecznie harcerskie. Uroczysta akademia. (26-30.03.1983)

Ikoniczny kult patrona - generała Karola Świerczewskiego - ma charakter wszechogarniający, nie sprowadza się tylko do spektakularnych jubileuszy i dat. Do kroniki trafia na przykład wspomnienie - w ilustracyjnej czarnej tonacji, z kwietną kolorową wyklejanką: „XXIX rocznica śmierci generała Waltera” (26.03.1976). Rok później w kronice zostaje zamieszczona biało-czerwona szarfa $\mathrm{z}$ autografami uczestników jubileuszowej akademii oraz wpinkowym znaczkiem w czerwonej tonacji z motywem żołnierskiego hełmu i karabinu oraz datami 1947-1977 i napisem: „XXX-lecie hołdu pamięci Patrona Szkoły gen. K. Świerczewskiego”. Wcześniejsza aktualizacja daje w konsekwencji możliwość, by owa powtarzana przez trzydzieści lat, zakładać należy, niezmiennie i nieprzerwanie postawa czci mogła się przerodzić w swoiście piętrowy jubileusz jubileuszu hołdu.

Intensyfikacja i piętrzenie się bodźców o charakterze zarówno informacyjnym, ideowym, jak i propagandowym są niezwykle zróżnicowane. W innym roku w dniach bliskich obchodom uroczystości patrona szkoły w kronice znajdujemy zestawienie podjętych inicjatyw:

Konkurs „Szklakiem II Armii LWP”. Uroczyste lekcje w klasach i Izbie Pamięci. Poranek poświęcone Patronowi Szkoły. Warty w Izbie Pamięci. Uroczyste warty przy pomniku gen. Świerczewskiego. Złożenie kwiatów przez delegacje klas. Wystawa kronik klasowych. „Był taki Generał” audycja TV. (26-30.03.1984) 
Cykliczność i intensyfikacja działań ma tu jednakowo wymiar rytualizowanej liturgii oraz wzmożenia propagandowego, które angażuje zarówno na płaszczyźnie rywalizacji, jak i emocjonalnej i intelektualnej (konkursy wiedzy, występy artystyczne, warta pod pomnikiem czy w Izbie Pamięci Narodowej). Bodźce te mają za zadanie emocjonalizowanie odbioru przedstawianych treści, podbudowywanie dumy $\mathrm{z}$ uczestniczenia w wydarzeniach o historycznym i podniosłym charakterze, co przywołuje używana chętnie leksyka (uroczyste lekcje, uroczyste warty, pamięć, naród).

Intensywność działań propagandowych ma charakter kampanijny i totalizujący. Dobrze ilustruje to zestaw fotografii i podpisów, które streszczają tematykę podejmowanych w szkole działań jednocześnie wychowawczych i ideowych:

Szkolny Samorząd Uczniowski na rok bieżący ma ambitne plany. Przygotowujemy się do obchodów XX-lecia szkoły. Uroczyście uczcimy XXXV-lecie powstania LWP oraz XXX-lecie utworzenia PZPR. Do wieczornicy z okazji WSRP przygotowuje się szkolne TPPR. (10.09.1978)

Wspomniana historyczność zdarzeń wojennych jest przez używane w tym dyskursie narzędzia niezmiennie aktualizowana. Dzieje się to zarówno w przestrzeni fizycznej: urządzonej w szkole i wzbogacanej o eksponaty Izbie Pamięci Narodowej (poświęconej wysiłkowi militarnemu w czasie II wojny światowej), jak i we wpisach w kronice: z jednej strony archiwizującej zdarzenia, które się w szkole rozgrywają, z drugiej - budującej z samej kronikarskiej opowieści narzędzie dydaktyki historycznej.

Dobór zdarzeń, naświetlanie ich, selekcja mają w kronice wyraźnie strategicznie nakreślone przebiegi. Otrzymujemy więc liczne wpisy dotyczące wypraw krajoznawczych. Są to najczęściej, jeśli wycieczka szkolna odbywa się na większą odległość, turnusy jednoznacznie propagandowe: na Westerplatte, do Warszawy - traktowanej jako wzór niezłomności i miasto-bohater: „Warszawa - to Miasto Bohater. Miasto pomników - pamiątek upamiętniających martyrologię Państwa Polskiego" (14.04.1973) czy do Oświęcimia (relatywnie rzadziej, a jeśli już, to niezmiennie traktowanego jako miejsce kaźni Polaków). Owo punktowe oświetlanie miejsc i przestrzeni wiąże się z kontekstem budowania pamięci wspomaganej artefaktami (z przestrzeni Izby Pamięci), a także logicznie układa się w spójną opowieść wiążącą się z patronem - Karolem Świerczewskim, który urodził się i wychował w Warszawie, tam też został pochowany, czy też szerzej — z polskim żołnierzem, którego los, walkę i bohaterstwo również lokalizowano w centralnej Polsce, wskazując na walki obronne września 1939 roku czy bitwy rozstrzygające o przesuwaniu się frontu w roku 1944/1945.

Powiązania dydaktyczne i emocjonalne ilustrujące to spostrzeżenie znajdujemy na przykład w kronikarskiej relacji z wycieczki do stolicy:

Program wycieczki zakładał:

— zwiedzenie zabytków: Starówki, katedry, pomników;

— wizytę w Pałacu Nauki i Kultury;

— honorową wartę przy grobie gen. Karola Świerczewskiego na Powązkach. (24-27.09.1978) 
Obiegowe cytaty o charakterze perswazyjno-propagandowym także odwołują się do tego schematycznego zestawu wątków i skojarzeń symbolicznych. Z okazji 33. rocznicy zakończenia wojny w kronice pojawia się odpowiedni wpis z czterowierszem:

[...] nam się okno szeroko otwiera

Nad Wisłą i Odrą, i Nysą.

Ojczyzno Waltera, Ojczyzno Szopena

Waleczna, Ludowa Ojczyzno. (9.05.1978)

Kolekcja we wskazanym przykładzie przeistacza się w pozornie logiczny ciąg zdarzeń, które budują jednorodną, uzasadnioną fabułę.

W narracji mitycznej zdarzenia są w maksymalnym stopniu zdeterminowane - i między innymi dlatego właśnie znaczą [...], każde słowo, wypowiedziane przygodnie w takiej czy innej sytuacji, należy do ustalonego porządku świata (po stronie słusznej bądź niesłusznej), a więc zajmuje dokładnie wyznaczone miejsce na scenie - i tym samym ma wyrazisty sens, którego żadną miarą kwestionować nie można. Sens przedustawny, z góry założony, autorytatywnie do wierzenia podany. (Głowiński 1992: 31)

Dlatego też niewiele można w kronice znaleźć odniesień. Brakuje dowodów chociażby na kultywowanie pamięci o wyzwalaniu okolic Strzelina przez żołnierzy idących na Berlin i samych wyzwolicielach. Ekstrapolowanie wydarzeń realnych do sfery odległej również przestrzennie daje zapewne dysponentowi przekazu pewne bezpieczeństwo i margines błędu: można bowiem dość dowolnie żonglować faktami, postaciami i wyobrażeniami zdarzeń, które w przestrzeni lokalnej są zablokowane w ewentualnych wysiłkach weryfikacyjnych. Te, jeśli mają nastąpić, łączy się z pionierami - osadnikami, którzy organizują po kwietniu 1945 roku życie repatriantów przybywających na Ziemie Odzyskane.

W kronikarskiej opowieści wojna jest wyłącznie mężczyzną, tym, który walczy, chroni, tym, który już w cywilnym, pokojowym świecie odbiera należne mu hołdy: "A gdy wrócisz do domu — mój mały przyjacielu — to najserdeczniej, najszczerzej ucałuj Ojca, który był kiedyś żołnierzem” (1.06.1979, Międzynarodowy Dzień Dziecka, akademia miejsko-gminna).

Perswazyjny wykład szkolnej kroniki nie tyle ma problem z ukazaniem różnych emocji, wyważeniem tego, co w czasie wojny i okupacji było najważniejszym problemem dla różnych społeczności, warstw, grup społecznych, ile konsekwentnie pomija te rozróżnienia, stosując jednoznaczną i bezwyjątkową wykładnię: wysiłek militarny i braterstwo broni staje się tu jedynym godnym zauważenia (lub może jedynym możliwym do propagandowego zastosowania) wzorcem i obrazem skupiającym na sobie emocje, dającym możliwość łatwej orientacji aksjologicznej i budzącym jednoznacznie pozytywne emocje. Zapewne trudniej byłoby się tu posłużyć innymi obrazami: cierpieniem ludności cywilnej, losami kobiet czy dzieci, wysiłkiem pozafrontowym dla utrzymania machiny wojskowej. Wszystko to pozostaje poza horyzontem problemów oświetlanych przez kronikarską opowieść. Gdy w kronice pojawiają się dedykacje od żołnierzy (starannie opisywanych i autoopisujących się jako żołnierze Armii Czerwonej/Radzieckiej, ewentualnie żołnierze Armii Czerwonej, którzy następnie 
zostali wcieleni do Ludowego Wojska Polskiego), pojawiają się przesłania z propagandowym podtekstem, nawiązujące do konsekwentnie realizowanej opowieści odnoszącej się do sceny wojny jako nieustannie aktualizowanej groźby: „Żyć w pokoju jest szczęściem ludzkości. Życzeniem żołnierza frontowego, by nigdy świat nie zaznał grozy wojny. Dla młodzieży największym nakazem jest nauka” (9.05.1984).

Figura żołnierza w kronikarskim zapisie balansuje na granicy personalizacji. Pojawia się w swoistym uogólnieniu albo przybiera postać konkretnego kombatanta, pozwala to na uogólnienie cech bohaterstwa i męstwa, przypisywanie ich dowolnie: reprezentantom wojska lub stanowi żołnierskiemu jako takiemu. Przypisuje się apriorycznie męstwo, a także podziw świata dla jego niezłomności i odwagi, jak w uwiecznionej w kronice rymowance:

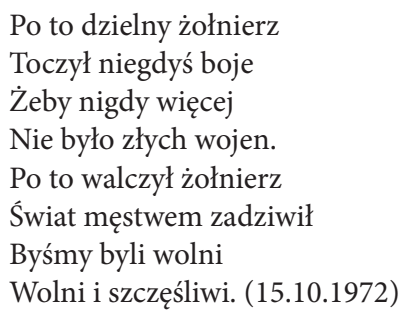

Programowo realizowany wykład o braterstwie broni przynosi dowody na intensywność, kampanijność działań propagandowych w przestrzeni szkolnej (organizacja izb pamięci narodowej, kompletowanie i uzupełnianie w nich materialnych dowodów kultu żołnierskiego i frontowego), dni patrona (o ile był nim reprezentant służb mundurowych), kultu godła, hymnu i barw narodowych, ale wyraźnie postrzeganych jako wartości, które wywodzą się z przestrzeni walki i wojny, podlegają ochronie militarnej (nie cywilnemu, obywatelskiemu szacunkowi czy kultowi), podtrzymywania, o ile istniały, lub budowania kultu bohaterów czy nawiązywania i podtrzymywania relacji z żyjącymi uczestnikami walk frontowych w roku 1945.

Podejmowane przez propagandę wysiłki ostatecznie nie przynosiły w szerszej skali pozytwnych efektów, co trafnie ujmuje Osęka:

propaganda coraz wyraźniej grzęzła w sprzecznościach. Z jednej strony wciąż zapewniano obywateli, że tylko ustrój socjalistyczny pozwoli zbudować świat bez wojen, z drugiej — całą młodzież objęto wieloetapowym, bo zaczynającym się już w podstawówce, przysposobieniem wojskowym, a przebrani w mundury śpiewacy dziarsko porykiwali z telewizora „przyjedź mamo na przysięgę". Młodzi Polacy nie dali się oszukać ani pacyfistycznymi sloganami, ani obietnicami „żołnierskiej przygody" [...]. Obowiązkowa służba wojskowa była jak dopust boży. (Osęka 2010: 45)

Obrazy wojny i żołnierza, jak wynika z lektury kroniki, są dalece spetryfikowane, odtwarzają na małą skalę wypracowane w przestrzeni ogólnokrajowej czy nawet międzynarodowej scenariusze, $\mathrm{z}$ podobną scenografią, scenariuszem, $\mathrm{z}$ wykorzystaniem zbliżonych elementów dekoracyjnych, które niosły z sobą spójne i powtarzalne komunikaty o treści ideologicznej, a nie tylko estetycznej. Kurczowe trzymanie się tych wzorców, ich sztampowość i nawrotowość zarówno prowadziły do wykształcenia się powtarzalnych i realizowanych niezmiennie schematów, jak 
i podają w wątpliwość sens ich szczegółowego i ponawianego dokumentowania. Jest ono dopełnieniem rytuału, nie zaś spontaniczną odpowiedzią na bieg zdarzeń, nie są podyktowane chęcią ich dokumentowania dla przyszłych pokoleń.

Propagandowe natężenie zdarzeń, uroczystości, jubileuszy, upamiętnień daje w efekcie niekończący się strumień materiałów, które ujednolicają emocjonalnie i merytorycznie przekaz, sprowadzając go do jednolitej opowieści o charakterze militarnym, ustawiają wszystkie wydarzenia w perspektywie wojny (realnej, historycznej lub opresji wojny zbliżającej się, nieustannie aktualizowanej jako zagrożenie, wobec którego ma się odbywać integracja i konsolidacja zbiorowości - w tym wypadku dzieci i młodzieży) wokół kultu munduru i żołnierskiego wysiłku frontowego i pozafrontowego. Stale łączy się je z wartościami bliskimi szkole: rywalizacji w osiąganych sukcesach dydaktycznych, wysokiej frekwencji w szkole czy udziału i zwycięstwach w zawodach sportowych, a także aktywności na rzecz lokalnego środowiska. Ich zwieńczeniem jest podsumowywanie ich i nagradzanie: pucharem przechodnim dyrektora szkoły (dla poszczególnych grup wiekowych) i przyznawaniem zwycięzcom proporczyka „Walterowiec”.

Liczne wpisy, ich propagandowe usytuowanie, zapośredniczanie treści znanych skądinąd, realnie więc zacieranie czy kwestionowanie gatunkowej funkcji kroniki (w tym kroniki szkolnej), wskazują, że była ona traktowana jako narzędzie oddziaływania propagandowego. Ciekawym zagadnieniem jest status autora i czytelnika (adresata idealnego i realnego) tego typu komunikacji. Wydaje się, że role te są tu kształtowane umownie. Nadawca nie czyni ze swojej funkcji realnego użytku, nie prowadzi kroniki jako ten, który stara się z przesłaniem historycznej troski o pamięć minionych zdarzeń zachować dla potomnych okruchy rzeczywistości. Wpisuje się w powierzoną mu rolę tego, którego zadaniem jest upewnienie się, że praca wychowawcza i ideowa instytucji szkolnej przebiega prawidłowo, że realizowany program znajduje swoje odniesienie w życiu szkoły, wysiłku wychowawczym zespołu pedagogicznego, a także że skutecznie wpływa na kształtowanie postaw ideowych dzieci i młodzieży.

Kronika szkolna tego czasu oczywiście jest i pozostanie materialnym dowodem dokumentalnym i archiwalnym, który może być źródłem do badań rzeczywistości lat PRL, życia codziennego i prywatnego tego czasu. Mimo wszystkich jej wad, presji, której poddaje się jako zespół utrwalonych tekstów, ze strony machiny propagandowej i oficjalnej wykładni idei oświaty socjalistycznej, zachowuje (lub może: mimowolnie przemyca) obrazy rzeczywistości, realne działania zaangażowanych osób, emocje i przeżycia dziecka, pierwsze dni w szkole, emocje rywalizacji sportowej, sukcesy edukacyjne w konkursach i olimpiadach, ale też ówczesne mniej lub bardziej akceptowane i spontaniczne modele spędzania czasu: w kołach przedmiotowych, pracy wolontariackiej czy współpracy z lokalnymi instytucjami, pracy wychowawczej w Związku Harcerstwa Polskiego, a także - czego ukrywać zapewne nie ma potrzeby - zadowolenia $\mathrm{z}$ wysiłku wkładanego w te działania, które system dekretował jako cenne i wartościowe: występów artystycznych, inscenizacji, wart w miejscach pamięci czy pod lokalnymi pomnikami, czy też uczestnictwa w ma- 
nifestacjach i pochodach jako formie nie tylko indoktrynacyjnego przymusu, lecz także po prostu rozrywki czy młodzieżowej rywalizacji pomiędzy szkołami. Emocje te zapisuje się w kronice, określając tak: „Nasz szkoła otrzymała miłe wyróżnienie: miała zaszczyt inaugurowania pochodu młodzieży szkół strzelińskich” (1.05.1979).

Osobliwość prezentowanego tu materiału jest raczej innego gatunku: osadzona jest w zakwestionowaniu spontaniczności pracy kronikarskiej (i jej, co charakterystyczne, anonimowości), wyraźnej selekcji zdarzeń i faktów, budujących propagandową interpretację wizerunku żołnierza i semantykę obrazu wojny, prowadzenia jako wykładu ideologicznego, a nie realnej próby dokumentowania świata szkoły jako społeczności.

\section{Bibliografia}

Borkowski I. (2003): Świt wolnego słowa. Język propagandy politycznej 1981-1995, Wrocław.

Dytman-Stasieńko A. (2006): Święto zawłaszczonych znaczeń. 1 maja w PRL - ideologia, rytuał, język, Wrocław.

Głowiński M. (1991): Nowomowa po polsku, Warszawa.

Głowiński M. (1992): Rytuał i demagogia. Trzynaście szkiców o sztuce zdegradowanej, Warszawa.

Głowiński M. (1996): Mowa w stanie oblężenia: 1982-1985, Warszawa.

Głowiński M. (1999): Końcówka: czerwiec 1985-styczeń 1989, Kraków.

Kamińska-Szmaj I. (2001): Słowa na wolności, Wrocław.

Kamińska-Szmaj I. (2007): Agresja językowa $w$ życiu publicznym. Leksykon inwektyw politycznych 1918-2000, Wrocław.

Osęka P. (2010): Mydlenie oczu. Przypadki propagandy w Polsce, Kraków.

Ożóg K. (2004): Język w stużbie polityki. Językowy kształt kampanii wyborczych, Rzeszów.

Słomianowska-Kamińska E. (2006): Druki ulotne w polityce (wybrane druki wyborcze - ich znaczenia i funkcje, [w:] Druki ulotne i okolicznościowe - wartości i funkcje, red. K. Migoń, M. Skalska-Zlat, A. Żbikowska-Migoń, Wrocław, s. 126-141.

Smoleński P. (2017): Syrop z piołunu. Wygnani w akcji „Wista”, Wołowiec.

Śleziak M. (2016): Ziemie Odzyskane w drukach ulotnych $z$ lat 1945-1948, Wrocław.

\section{School chronicle - a specific tool for shaping the image of the war and the soldier}

\section{Summary}

The status of the school chronicle as a genre documenting social life may seem dysfunctional from today's perspective. Nowadays, there are other channels of communication and other means of transferring values, shaping attitudes and setting examples.

However, the school chronicle can still be an interesting resource illustrating the contemporary means and tools - actualized in the messages of persuasion and propaganda - which effectively influence the attitudes, ideas, views and decisions of recipients, as well as shape their attitudes and construct personal patterns of parenetic character. The text focuses on the analysis of material from school chronicles which concerns the image of war and that of the soldier.

Keywords: propaganda, war, soldier, school chronicle. 